\title{
Assembling one-dimensional coordination polymers into three- dimensional architectures via hydrogen bonds
}

\author{
LALIT RAJPUT, MADHUSHREE SARKAR and KUMAR BIRADHA* \\ Department of Chemistry, Indian Institute of Technology, Kharagpur 721302 \\ e-mail: kbiradha $@$ chem.iitkgp.ernet.in
}

\begin{abstract}
The reactions of bis(pyridylcarboxamido)alkanes (amides) and bis(3-pyridyl)alkanediamides (reverse amides) with copper(II) and zinc(II) in the presence of various anions resulted in onedimensional polymeric crystalline complexes with or without guest inclusion. The crystal structure analyses of these complexes reveal that the one-dimensional networks observed here are of three types: simple linear chain, chains with wavy nature and chains containing cavities. The self-complementary amide groups of the ligands assembled these coordination networks into higher dimensional architectures via $\mathrm{N}-\mathrm{H} \cdots \mathrm{O}$ hydrogen bonds.
\end{abstract}

Keywords. Coordination polymers; hydrogen bonds; self-assemblies; $\beta$-sheet; guest inclusion.

\section{Introduction}

Crystal engineering is aimed at the designing periodic structures of desired supramolecular organization and has potential applications in the field of magnetism, conductivity, sensors, nonlinear optics, host-guest chemistry, catalysis, separation science, gas storage and so on. ${ }^{1-3}$ The concepts of crystal engineering are based on understanding and exploiting the intermolecular interactions. There are several crystal engineering studies on metal-organic hybrid materials that are purely based on coordination bonds and also on organic materials that are purely based on hydrogen bonds. ${ }^{4}$ However, the utilization of hydrogen bond supramolecular synthons in assembling metal-organic frameworks is relatively less explored area of research. The combination of these two aspects is expected to result in more control over the network geometries and therefore the properties. The aim of the present work is to apply the supramolecular synthon approach for assembling the coordination networks by designing the ligands containing functional groups which are capable of forming the hydrogen bond synthons and the coordination bonds (scheme 1). The coordination networks of these ligands are expected to fulfill the following objectives: (i) introduces the functional groups into the polymeric networks; (ii) these functional groups help in fine tuning the nature of the

\footnotetext{
*For correspondence
}

cavities to accommodate wide range of guest molecules; (iii) self recognition synthons act as communicators and assembles polymeric networks into various novel architectures.

Recently we have explored the recognition patterns of amides and reverse amide ligands (1-3) and found that amides and reverse amides, which have the same combination of functional groups at the molecular level, behave very differently at supramolecular level. It was shown in case of amide analogues that even in the presence of pyridine groups; the amide groups form amide-to-amide hydrogen bonds whereas in case of reverse amide analogues, pyridine group exhibits interference in amide-to-amide hydrogen bonds and disrupts the amide-to-amide recognition pattern. ${ }^{5}$

In our previous studies using ligands 1,2 and 3 we have also shown that $\mathrm{Cu}$ (II) salts are capable of forming various open 2D-networks, chiral 2Dnetworks, interpenetrated 2D-networks (both parallel and perpendicular mode) and 3D pseudo diamondoid (6 6 -topology) networks. ${ }^{6}$ In several instances these networks exhibit recognition through amideto-amide hydrogen bonds namely $\beta$-sheet hydrogen bonding pattern. Here we discuss our results on one-dimensional networks of $\mathbf{1}, \mathbf{2}$ and $\mathbf{3}$ with $\mathrm{Cu}\left(\mathrm{CH}_{3} \mathrm{COO}\right)_{2}, \mathrm{Cu}\left(\mathrm{NO}_{3}\right)_{2} \mathrm{Cu}(\mathrm{SCN})_{2}, \mathrm{CuSO}_{4}, \mathrm{ZnI}_{2}$ and $\mathrm{Cu}\left(\mathrm{ClO}_{4}\right)_{2}$.

Among polymeric networks, the one-dimensional networks are of the simplest coordination polymers observed with bidentate ligands. ${ }^{7}$ The primary reason 
<smiles>[H][Y]([H])([H])NC(=O)c1cccnc1</smiles><smiles>[H][Y]([H])(NC(=O)c1ccncc1)NC(=O)c1ccncc1</smiles><smiles>O=C(Nc1ccncc1)Nc1ccncc1</smiles>

$\mathbf{a}: \mathrm{X}=\left(\mathrm{CH}_{2}\right)_{2} ; \mathbf{b}: \mathrm{X}=\left(\mathrm{CH}_{2}\right)_{4} ; \mathbf{c}: \mathrm{X}=\left(\mathrm{C}_{6} \mathrm{H}_{4}\right)$

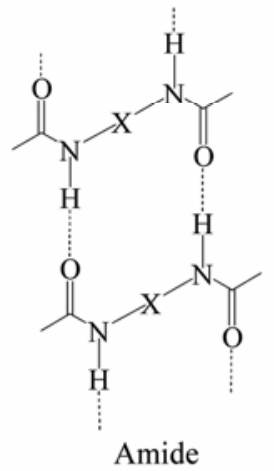<smiles>[R]C(=O)OCCCCCNC(=O)C([X])NC</smiles>

Scheme 1. Exobidentate ligands with bis(amido)alkane spacer; $\beta$-sheet networks.

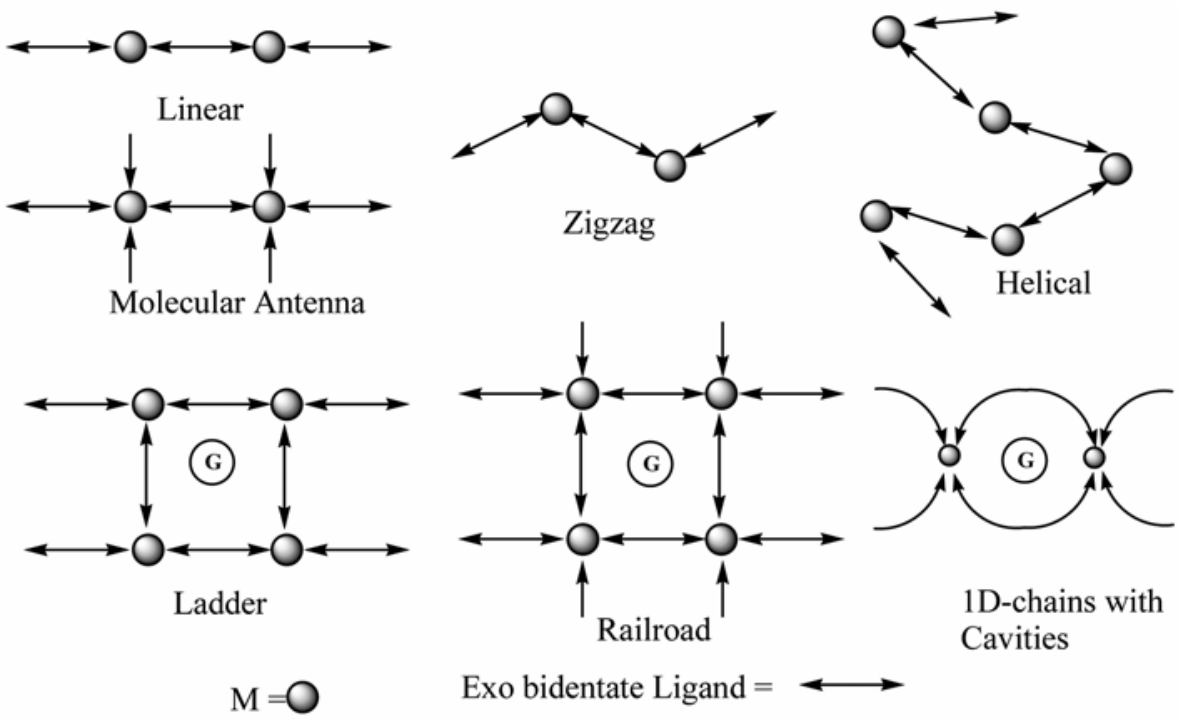

Scheme 2. 1D-networks with exobidentate ligand.

for the formation of 1D-chains may be due to the presence of other competing ligands such as anions, $\mathrm{H}_{2} \mathrm{O}$ or solvents in the reaction of the bidentate ligand with the metal centre. Various possible geometries are known for 1D-networks with linear rigid bidentate ligands: linear, ${ }^{8}$ zigzag, ${ }^{9}$ helical, ${ }^{10}$ ladder, ${ }^{11}$ molecular antenna, ${ }^{12}$ railroad $^{13}$ and $1 \mathrm{D}$ chains with cavities ${ }^{14}$ (scheme 2 ). The formation of these networks depends on the ligand to metal ratio, coordination environment of the metal centre and influence of counter anions and guest/solvent molecules. The role of these amide groups in assembling the one-dimensional coordination networks and the effect of various factors such as counter anions and solvent molecules on the occurrence of amide-toamide hydrogen bonds will be presented here.

\section{Experimental}

\subsection{Materials}

All the reagents and solvents employed were commercially available and used as supplied without further purification. $\mathrm{Cu}\left(\mathrm{NO}_{3}\right)_{2}, \mathrm{Cu}(\mathrm{OAc})_{2}, \mathrm{CuSO}_{4}$, 
$\mathrm{ZnI}_{2}, \mathrm{NaSCN}, \mathrm{Cu}_{2}\left(\mathrm{CO}_{3}\right)_{2}$ and perchloric acid were obtained from Merck $\mathrm{Co}$. $\mathrm{Cu}\left(\mathrm{ClO}_{4}\right)_{2}$ was prepared from $\mathrm{Cu}_{2}\left(\mathrm{CO}_{3}\right)_{2}$ and perchloric acid. The ligands were prepared according to the previously reported procedures. $^{5}$

\subsection{Physical measurements}

FTIR spectra were recorded with an NEXUS-870 instrument, Thermo Nicolet Corporation. Elemental analyses were obtained with a Perkin Elmer instrument, series II, CHNS/O analyzer 2400. TGA data were recorded with a Perkin Elmer instrument, Pyris Diamond TG/DTA $\left(\mathrm{N}_{2}\right)$.

\subsection{Syntheses of complexes}

The complexes 4-7, 9 and 10 were prepared by adopting the layering technique. The complexes $\mathbf{8}$ and 11 were prepared by direct mixing of ligand with metal in the presence of aromatic guest molecules.

2.3a Synthesis of complex $\mathbf{4}$ by layering: The ligand 1a $(54.0 \mathrm{mg}, 0.2 \mathrm{mmol})$ was taken in $\mathrm{CHCl}_{3}$ EtOH $(10: 1)$ solvent $(5.5 \mathrm{~mL})$. An ethanolic solution $(1.0 \mathrm{~mL})$ of $\mathrm{Cu}\left(\mathrm{NO}_{3}\right)_{2} \cdot 6 \mathrm{H}_{2} \mathrm{O}(24.1 \mathrm{mg}, 0.1 \mathrm{mmol})$ was slowly layered over the ligand solution. The slow diffusion of the components resulted in the formation of blue coloured crystals after one week. Yield: $36 \cdot 1 \%$; Elemental analysis: $\mathrm{C}_{28} \mathrm{H}_{44} \mathrm{~N}_{12} \mathrm{O}_{24} \mathrm{Cu}_{2}$ (1059.8): Calculated: $\mathrm{C} 31.73 \%, \quad \mathrm{H} 4.18 \%$, N $15.86 \%$; Found: C $30.60 \%$, H $4.09 \%$, N $15.58 \%$.

2.3b Syntheses of complex 5 and 6: Complexes 5 and 6 were prepared in similar way by the reaction of ligand $\mathbf{1 b}$ with $\mathrm{Cu}(\mathrm{OAc})_{2}$ and $\mathrm{ZnI}_{2}$, respectively. Complex 5: Yield: 28.7\%; Elemental analysis: $\mathrm{C}_{22} \mathrm{H}_{26} \mathrm{~N}_{4} \mathrm{O}_{9} \mathrm{Cu}_{1}$ (553.5) Calculated: C 47.69\%, H $4.69 \%$, N $10 \cdot 11 \%$; Found: C $47 \cdot 13 \%$, H $4.76 \%$, N 10.60\%. Complex 6: Yield: $20.3 \%$; Elemental analysis: $\mathrm{C}_{18} \mathrm{H}_{18} \mathrm{~N}_{4} \mathrm{O}_{4} \mathrm{I}_{2} \mathrm{Zn}_{1} \quad(673 \cdot 1)$ : Calculated: $\mathrm{C}$ $32.09 \%$, H 2.67\%, N 8.31\%; Found: C $32.16 \%$, H $2 \cdot 58 \%$, N $8.35 \%$

2.3c Syntheses of complex 7: The ligand 2a $(54.0 \mathrm{mg}, 0.2 \mathrm{mmol})$ was taken in $\mathrm{CHCl}_{3}-\mathrm{EtOH}$ $(10: 1)$ solvent $(5.5 \mathrm{~mL})$. An ethanolic solution $(1.0 \mathrm{~mL})$ of $\mathrm{Cu}\left(\mathrm{ClO}_{4}\right)_{2} \cdot 6 \mathrm{H}_{2} \mathrm{O}(37.0 \mathrm{mg}, 0.1 \mathrm{mmol})$ was slowly layered over the ligand solution. The slow diffusion of the components resulted in the formation of purple coloured crystals after one week. Yield: $61 \cdot 1 \%$; Elemental analysis: $\mathrm{C}_{38} \mathrm{H}_{42} \mathrm{Cl}_{8}$ $\mathrm{Cu}_{1} \mathrm{~N}_{8} \mathrm{O}_{14}$ (1181.94): Calculated: C 38.58\%, H 3.55\%, N 9.47\%; Found: C 38.46\%, H 3.51\%, N 9.39\%.

2.3d Synthesis of complexes 8: Ethanolic solution $(20 \mathrm{~mL})$ of $\mathrm{Cu}\left(\mathrm{ClO}_{4}\right)_{2} \cdot 6 \mathrm{H}_{2} \mathrm{O}(370 \cdot 15 \mathrm{mg}, 1.0 \mathrm{mmol})$ was added to a stirred solution $(30 \mathrm{~mL}$ of $\mathrm{EtOH})$ of ligand 1a $(540 \mathrm{mg}, 2.0 \mathrm{mmol})$ and naphthalene $(2.56 \mathrm{~g}, 20 \mathrm{mmol})$. This resulted in the formation of a blue precipitate. After $15-20 \mathrm{~min}$ of stirring, $20 \mathrm{~mL}$ of water was added. The blue precipitate became soluble and a clear solution was obtained. This solution was filtered and kept for slow evaporation. Blue coloured crystals were formed after one week. For the inclusion of liquid aromatic guest molecules, $20 \mathrm{~mL}$ of the corresponding liquid was taken in place of naphthalene.

8•Naphthalene (8a): Yield: 83.7\%; Elemental Analysis: $\mathrm{C}_{38} \mathrm{H}_{44} \mathrm{~N}_{8} \mathrm{O}_{16} \mathrm{Cl}_{2} \mathrm{Cu}_{1}$ (1003.5): Calculated: C $45.48 \%$, H $4.38 \%$, N $11.17 \%$; Found: C 46.06\%, $\mathrm{H} 4.44 \%$, N $11.43 \%$.

8•Toluene (8b): Yield: 76.1\%; Elemental Analysis: $\mathrm{C}_{35} \mathrm{H}_{44} \mathrm{~N}_{8} \mathrm{O}_{16} \mathrm{Cl}_{2} \mathrm{Cu}_{1} \quad$ (967.2): Calculated: $\mathrm{C}$ $43.45 \%$, H $4.55 \%$, N $11.50 \%$; Found: C $43.65 \%$, H $4 \cdot 37 \%, \mathrm{~N} 11 \cdot 35 \%$.

8•Ethylbenzene (8c): Yield: 80.6\%; Elemental analysis: $\mathrm{C}_{36} \mathrm{H}_{46} \mathrm{~N}_{8} \mathrm{O}_{16} \mathrm{Cl}_{2} \mathrm{Cu}_{1}(980 \cdot 5)$ : Calculated: $\mathrm{C}$ $44.05 \%$, H $4.69 \%$, N $11.42 \%$; Found: C $43.40 \%$, H $4.66 \%, \mathrm{~N} 11.51 \%$.

8•Anisole (8d): Yield: $73.0 \%$; Elemental analysis: $\mathrm{C}_{35} \mathrm{H}_{44} \mathrm{~N}_{8} \mathrm{O}_{17} \mathrm{Cl}_{2} \mathrm{Cu}_{1}$ (982.5): Calculated: $\mathrm{C} 42.74 \%$, H $4.47 \%$, N $11.39 \%$; Found: C $43.18 \%$, H $4.39 \%$, N $11.41 \%$.

2.3e Synthesis of complex 9 by layering: Ethanolic solution of ligand $(2 \mathrm{~mL}) 3 \mathbf{a}(27 \mathrm{mg}, 0.1 \mathrm{mmol})$ was layered over aqueous solution $(5 \mathrm{~mL})$ of $\mathrm{Cu}\left(\mathrm{ClO}_{4}\right)_{2} \cdot 6 \mathrm{H}_{2} \mathrm{O}(12.48 \mathrm{mg}, 0.05 \mathrm{mmol})$. After 15 days green coloured crystals were formed at the interface of the two layers. Yield: $27.40 \%$.

2.3f Synthesis of complex $\mathbf{1 0}$ by layering: Complex 10 was prepared in similar way as of 9 by the reaction of ligand $3 \mathrm{~b}$ with $\mathrm{CuSO}_{4}$. Yield: $43.23 \%$; Elemental analysis: $\mathrm{C}_{16} \mathrm{H}_{30} \mathrm{~N}_{4} \mathrm{O}_{12} \mathrm{SCu}(566 \cdot 04)$ : Calculated: C, 33.95\%; H, 5.34\%; N, 9.90\%; Found: C, $34.38 \% ; \mathrm{H}, 5 \cdot 07 \% ; \mathrm{N}, 10 \cdot 0 \%$.

2.3g Synthesis of complex 11 by direct mixing: $63.6 \mathrm{mg}(0.2 \mathrm{mmol})$ of $\mathbf{3 c}$ was dissolved in $3 \mathrm{~mL}$ of 
DMSO. To this solution methanol $(2 \mathrm{~mL})$ solution of $\mathrm{Cu}\left(\mathrm{NO}_{3}\right)_{2}(24.16 \mathrm{mg}, 0.1 \mathrm{mmol})$ and $\mathrm{NaSCN}$ $(16.21 \mathrm{mg}, 0.2 \mathrm{mmol})$ was added. After a week, green coloured crystals were formed. Yield: $54.64 \%$; Elemental analysis: $\mathrm{C}_{24} \mathrm{H}_{26} \mathrm{~N}_{6} \mathrm{O}_{4} \mathrm{~S}_{4} \mathrm{Cu}(654.31)$ : Calculated: C, 44.05\%; H, 4.01\%; N, 12.84\%; Found: C, $44.42 \% ; \mathrm{H}, 4 \cdot 18 \%$; N, $12.35 \%$.

2.3h X-ray crystal structure determination: The single crystal data for 4-6 and 7-9 were collected on a Bruker-Nonius Mach3 CAD4 and CCD APEX-2 X-ray diffractometers, respectively, that uses graphite monochromated $\operatorname{MoK} \alpha$ radiation $(\mu=$ $0.71073 \AA$ ). The structures were solved by direct methods and refined by least square methods on $F^{2}$ using SHELX-97. ${ }^{17}$ In the structure 7, perchlorate ions are somewhat distorted and disordered, therefore $\mathrm{Cl}$-atoms are refined anisotropically and $\mathrm{O}$ atoms are refined isotropically. Further the solvent molecules which accounts for $23 \%$ of crystal volume could not be located, therefore Platon. ${ }^{18}$ squeeze option was used for the final refinement. Otherwise, non-hydrogen atoms in all the structures were refined anisotropically and hydrogen atoms were fixed at calculated positions and refined using a riding model. PLATON is used for the calculations guest available volumes. The crystal structures 5, 6 and 9-11 were deposited in the Cambridge data centre (depository numbers: CCDC 755602-755606).

\section{Results and discussion}

The complexes were synthesized either by direct mixing of the components or by the layering procedure. The complexes 4-6 are prepared by layering ethanolic solution of corresponding metal salt over the $\mathrm{CHCl}_{3} / \mathrm{EtOH}$ solution of ligands 1 . Whereas the complexes 7 and 8 were prepared by direct mixing of the ligand and $\mathrm{Cu}\left(\mathrm{ClO}_{4}\right)_{2}$ in $\mathrm{EtOH}$ and water. The complexes 9 and $\mathbf{1 0}$ were prepared by layering methanolic solution of $\mathbf{3 a}$ and ethanolic solution of $3 \mathbf{b}$ over the aqueous solution of $\mathrm{Cu}\left(\mathrm{ClO}_{4}\right)_{2}$ and $\mathrm{CuSO}_{4}$, respectively. The complex 11 was obtained by direct mixing of 3c, $\mathrm{Cu}\left(\mathrm{NO}_{3}\right)_{2}$ and $\mathrm{NaSCN}$ in DMSO and $\mathrm{MeOH}$.

$$
\begin{aligned}
& \left\{\left(\mathrm{Cu}(\mathbf{1} \mathbf{a})\left(\mathrm{H}_{2} \mathrm{O}\right)_{4}\right) \bullet 2\left(\mathrm{NO}_{3}\right)\right\}_{\mathrm{n}}, 4 \\
& \left\{\left(\mathrm{Cu}(\mathbf{1 c})\left(\mathrm{H}_{2} \mathrm{O}\right)\left(\mathrm{CH}_{3} \mathrm{COO}\right)_{2}\right) \bullet 2\left(\mathrm{H}_{2} \mathrm{O}\right)\right\}_{\mathrm{n}}, \mathbf{5} \\
& \left\{\left(\mathrm{Zn}(\mathbf{1 c}) \mathrm{I}_{2}\right) \bullet 2\left(\mathrm{H}_{2} \mathrm{O}\right)\right\}_{\mathrm{n}}, \mathbf{6} \\
& \left\{\left(\mathrm{Cu}(2 \mathrm{a})_{2}\left(\mathrm{ClO}_{4}\right)_{2}\right) \bullet 2\left(\mathrm{CHCl}_{3}\right) \bullet 2(\mathrm{EtOH})\right\}_{\mathrm{n}}, 7
\end{aligned}
$$

$$
\begin{aligned}
& \left\{\left(\mathrm{Cu}(\mathbf{1 a})_{2}\left(\mathrm{H}_{2} \mathrm{O}\right)_{2}\right) \bullet 2\left(\mathrm{ClO}_{4}\right) \bullet 2\left(\mathrm{H}_{2} \mathrm{O}\right)\right\}_{\mathrm{n}}, 8 \bullet \text {, }(\text { guest }) \\
& \left\{\left(\mathrm{Cu}(\mathbf{3 a})_{2} \bullet\left(\mathrm{ClO}_{4}\right) \bullet \mathrm{H}_{2} \mathrm{O}\right) \bullet\left(\mathrm{ClO}_{4}\right) \bullet 2 \mathrm{H}_{2} \mathrm{O}\right\}_{\mathrm{n}}, 9 \\
& \left\{\left(\mathrm{Cu}(\mathbf{3 b}) \bullet\left(\mathrm{H}_{2} \mathrm{O}\right)_{3} \bullet \mathrm{SO}_{4}\right] \bullet 3\left(\mathrm{H}_{2} \mathrm{O}\right)\right\}_{\mathrm{n}}, \mathbf{1 0} \\
& \left\{\left(\mathrm{Cu}(\mathbf{3 c}) \bullet(\mathrm{SCN})_{2} \bullet(\mathrm{DMSO})_{2}\right)\right\}_{\mathrm{n}}, \mathbf{1 1}
\end{aligned}
$$

The crystal structures of complexes 4-11 were determined and analysed in terms of coordination network geometries, recognition of networks through amide hydrogen bonds and effects of anions and guest molecules. The complexes 4-6 and 9-11 show the formation of 1D-chains but these 1Dchains differ from each other in many ways. The complexes 7 and 8 form 1D-chain with cavities for guest inclusion and have $1: 2$ metal to ligand ratio. The pertinent crystallographic details, bond lengths around metal centre and geometrical parameters of strong hydrogen bonds involving amides are given in tables 1,2 and 3 respectively. In the following section the crystal structures of complexes 4-11 will be discussed in detail.

\subsection{Crystal structures of complexes of amides}

3.1a $\mathrm{NO}_{3}^{-}$Included channels resulted from the packing of $1 D$ chains: In complex $\mathbf{4}$, the $\mathrm{Cu}(\mathrm{II})$ centre is octahedrally coordinated to two ligand (1a) units which occupy the axial positions while four water molecules occupy the equatorial positions (table 2, figure 1a). The alkyl spacer of the ligand adopts perfect anti conformation $(\mathrm{N}-\mathrm{C}-\mathrm{C}-\mathrm{N}$ torsion $180^{\circ}$ ) which resulted in the linear geometry of the ligand (figure 1a). The packing of the chains is governed by the hydrogen bonded interactions of amide spacers of the ligand $\mathbf{1 a}$ with the $\mathrm{NO}_{3}$ anions and water molecules. The $\mathrm{NO}_{3}$ anions form hydrogen bonds with amide $-\mathrm{NH}$ and coordinated $\mathrm{H}_{2} \mathrm{O}$ $\left(\mathrm{O}-\mathrm{H} \cdots \mathrm{ONO}_{2}\right.$ : $1.90 \AA, 2.702(4) \AA, 157^{\circ} ; 1.81 \AA$, $2 \cdot 660(4) \AA, 175^{\circ}$, figure 1a). The chains are further packed via hydrogen bond interactions between the amide $(\mathrm{C}=\mathrm{O})$ of one chain and coordinated $\mathrm{H}_{2} \mathrm{O}$ of another chain (figure $1 \mathrm{~b}$ ). The packing of the layers resulted in the formation of channels which are occupied by $\mathrm{NO}_{3}$ anions (figures $\mathrm{lb}$ and c).

3.1b ID Chain with wave-like features: In complex 5 , the $\mathrm{Cu}(\mathrm{II})$ centre adopts square pyramidal coordination geometry. The two ligand (1c) units occupy the two equatorial sites in a trans fashion, the other two equatorial sites are occupied by acetate anions and one water molecule is coordinated at the 
Table 1. Crystallographic data and structure refinement parameters for complexes 5, 6 and 9-11.

\begin{tabular}{|c|c|c|c|c|c|}
\hline Complex & 5 & 6 & 9 & 10 & 11 \\
\hline Formula & $\mathrm{C}_{22} \mathrm{H}_{26} \mathrm{Cu}_{1} \mathrm{~N}_{4} \mathrm{O}_{9}$ & $\mathrm{C}_{18} \mathrm{H}_{18} \mathrm{Zn}_{1} \mathrm{~N}_{4} \mathrm{O}_{4} \mathrm{I}_{2}$ & $\mathrm{C}_{28} \mathrm{H}_{30} \mathrm{Cl}_{2} \mathrm{Cu}_{1} \mathrm{~N}_{8} \mathrm{O}_{13}$ & $\mathrm{C}_{16} \mathrm{H}_{30} \mathrm{Cu}_{1} \mathrm{~N}_{4} \mathrm{O}_{12} \mathrm{~S}$ & $\mathrm{C}_{24} \mathrm{H}_{26} \mathrm{Cu}_{1} \mathrm{~N}_{6} \mathrm{O}_{4} \mathrm{~S}_{4}$ \\
\hline M. wt. & $554 \cdot 01$ & $673 \cdot 53$ & $821 \cdot 04$ & $566 \cdot 04$ & 654.29 \\
\hline System & Monoclinic & Monoclinic & Orthorhombic & Monoclinic & Monoclinic \\
\hline Space group & $C 2 / c$ & $P 2 / c$ & Aba2 & $P 2 / c$ & $P 2(1) / n$ \\
\hline $\mathrm{a}(\AA)$ & $26 \cdot 836(5)$ & $12 \cdot 302(3)$ & $35 \cdot 565(3)$ & $13 \cdot 1933(2)$ & $11.8971(1)$ \\
\hline $\mathrm{b}(\AA)$ & $6 \cdot 4400(1)$ & $7 \cdot 1400(1)$ & $26 \cdot 508(3)$ & $7 \cdot 9300(1)$ & $14 \cdot 8682(1)$ \\
\hline$c(\AA)$ & $15 \cdot 407(3)$ & $13 \cdot 683(3)$ & $9 \cdot 486(3)$ & $25 \cdot 363(3)$ & $16 \cdot 4846(2)$ \\
\hline$\alpha\left(^{\circ}\right)$ & 90 & 90 & 90 & 90 & 90 \\
\hline$\beta\left(^{\circ}\right)$ & $115 \cdot 85(3)$ & $114 \cdot 78(3)$ & 90 & $115 \cdot 41(4)$ & $92 \cdot 989(3)$ \\
\hline$\gamma\left({ }^{\circ}\right)$ & 90 & 90 & 90 & 90 & 90 \\
\hline$V\left(\AA^{3}\right)$ & $2396 \cdot 3(1)$ & $1091 \cdot 17$ & $8943 \cdot 1(2)$ & $2396 \cdot 8(6)$ & $2912 \cdot 0(5)$ \\
\hline$Z$ & 4 & 2 & 8 & 4 & 4 \\
\hline Den. $\left(\mathrm{mg} / \mathrm{m}^{3}\right)$ & 1.536 & $2 \cdot 050$ & $1 \cdot 220$ & $1 \cdot 569$ & $1 \cdot 492$ \\
\hline GOF on $F^{2}$ & 1.019 & $1 \cdot 181$ & $1 \cdot 370$ & $1 \cdot 048$ & 0.967 \\
\hline$R_{1}(I>2 \sigma(I))$ & $0 \cdot 0715$ & $0 \cdot 0459$ & $0 \cdot 0726$ & $0 \cdot 0466$ & $0 \cdot 0786$ \\
\hline$w R_{2}$ (on $F^{2}$, all data) & 0.2282 & $0 \cdot 1348$ & $0 \cdot 1924$ & $0 \cdot 1457$ & $0 \cdot 1981$ \\
\hline
\end{tabular}

For crystallographic data of 4,7 and 8 please see the reference ${ }^{6}$

Table 2. Bond lengths around M(II) centre in complexes 4-11.

\begin{tabular}{llll}
\hline Complex & \multicolumn{1}{c}{$\mathrm{M}(\mathrm{II})-\mathrm{N}(\AA)$} & \multicolumn{1}{c}{$\mathrm{M}(\mathrm{II})-\mathrm{H}_{2} \mathrm{O}(\AA)$} & \multicolumn{1}{c}{$\mathrm{M}(\mathrm{II})-$ Anion $(\AA)$} \\
\hline $\mathbf{4}$ & $2 \cdot 032(3)$ & $2 \cdot 022(2) ; 2 \cdot 245(3)$ & None \\
$\mathbf{5}$ & $2 \cdot 011(5)$ & $2 \cdot 373(7)$ & $1 \cdot 977(4) ; 2 \cdot 922(4)$ \\
$\mathbf{6}$ & $2 \cdot 055$ & None & $2 \cdot 547$ \\
7 & $2 \cdot 022(4)$ & None & $2 \cdot 668(6)$ \\
$\mathbf{8 a}$ & $2 \cdot 066(3) ; 2 \cdot 095(3)$ & $2 \cdot 414(3)$ & None \\
$\mathbf{8 b}$ & $2 \cdot 052(4) ; 2 \cdot 083(4)$ & $2 \cdot 403(4)$ & None \\
$\mathbf{9}$ & $1 \cdot 997(9)$ & $2 \cdot 471(1)$ & $2 \cdot 774(2)$ \\
& $1 \cdot 982(1)$ & & \\
& $2 \cdot 040(1)$ & & \\
& $2 \cdot 053(9)$ & & $1 \cdot 960(2)$ \\
$\mathbf{1 0}$ & $2 \cdot 015(2)$ & $2 \cdot 286(3)$ & \\
& $2 \cdot 027(3)$ & $1 \cdot 987(2)$ & $1.943(7)$ \\
& & $2 \cdot 677(3)$ & $1.962(7)$ \\
\hline $\mathbf{1 1}$ & $2 \cdot 019(5)$ & $2 \cdot 464(5)^{*}$ & \\
& $2 \cdot 028(5)$ & $2 \cdot 703(5)^{*}$ & \\
\hline
\end{tabular}

*DMSO coordination

axial site. The phenyl ring and the two pyridyl rings of the ligand 1c are coplanar (figure 2a). The combined effects of rigid spacer of the ligand 1c, 3-pyridyl group and the coordination of the ligands at the equatorial position of the metal centre resulted in the formation of wave-like 1D chain (figure 2b).

These 1D chains are packed via hydrogen bonded interactions between the coordinated $\mathrm{H}_{2} \mathrm{O}$ molecules and acetate anions to form a $2 \mathrm{D}$ layer $(\mathrm{O}-\mathrm{H} \cdots \mathrm{OAc}$ : 1.89(8) $\AA, \quad 2.789(6) \AA, \quad 165(8)^{\circ} ; \quad 1.82(8) \AA$, 2.761(7) $\AA, 173(5)^{\circ}$, figure $\left.2 b\right)$. These 2D-layers are further packed in a staggered fashion via $\mathrm{C}-\mathrm{H} \cdots \mathrm{O}$ hydrogen bonds between amide $\mathrm{C}=\mathrm{O}$ and pyridyl $-\mathrm{CH}$ group (figures $2 \mathrm{c}$ and $2 \mathrm{~d}$ ). The $-\mathrm{NH}$ of the amide groups is involved in hydrogen bonded interactions with free $\mathrm{H}_{2} \mathrm{O}$ molecules that are present in the crystal lattice (figure $2 \mathrm{~b}$ ).

3.1c Packing of $1 D$ chains via $\beta$-sheet type pattern: In complex $\mathbf{6}$, the $\mathrm{Zn}$ (II) centre adopts tetrahedral coordination environment with two units of 1c and two $\mathrm{I}^{-}$anions. The geometry of the ligand 1c is different from the previous complex. Unlike in complex $\mathbf{5}$, the geometry of $\mathbf{1 c}$ in $\mathbf{6}$ is non-coplanar 
Table 3. Geometrical parameters of strong hydrogen bonds of amide in complexes 4-11.

\begin{tabular}{lllll}
\hline Complex & \multicolumn{1}{c}{ Type $^{\mathrm{I}}$} & $\mathrm{H} \cdots \mathrm{A}(\AA)$ & $\mathrm{D} \cdots \mathrm{A}(\AA)$ & $\mathrm{D}-\mathrm{H} \cdots \mathrm{A}\left({ }^{\circ}\right)$ \\
\hline $\mathbf{4}$ & $\mathrm{O}(1 \mathrm{~W})-\mathrm{H}(2 \mathrm{~W}) \cdots \mathrm{O}(11)^{\mathrm{a}}$ & $1 \cdot 92$ & $2 \cdot 800(4)$ & 159 \\
& $\mathrm{O}(2 \mathrm{~W})-\mathrm{H}(4 \mathrm{~W}) \cdots \mathrm{O}(11)^{\mathrm{b}}$ & $2 \cdot 01$ & $2 \cdot 747(3)$ & 145 \\
& $\mathrm{~N}(12)-\mathrm{H}(12) \cdots \mathrm{O}(103)^{\mathrm{c}}$ & $2 \cdot 15$ & $2 \cdot 987(4)$ & 163 \\
$\mathbf{5}$ & $\mathrm{N}(12)-\mathrm{H}(12) \cdots \mathrm{O}(2 \mathrm{~W})^{\mathrm{d}}$ & $2 \cdot 18$ & $3 \cdot 034(7)$ & 170 \\
& $\mathrm{C}(15)-\mathrm{H}(15) \cdots \mathrm{O}(16)^{\mathrm{e}}$ & $2 \cdot 34$ & $3 \cdot 089(8)$ & 137 \\
$\mathbf{6}$ & $\mathrm{N}(10)-\mathrm{H}(10) \cdots \mathrm{O}(1 \mathrm{~W})^{\mathrm{f}}$ & $1 \cdot 99$ & $2 \cdot 831(8)$ & 166 \\
& $\mathrm{O}(15) \cdots \mathrm{O}(1 \mathrm{~W})^{\mathrm{g}}$ & & $2 \cdot 726(8)$ & \\
$\mathbf{8 a}$ & $\mathrm{N}(21)-\mathrm{H}(21) \cdots \mathrm{O}(16)^{\mathrm{h}}$ & $2 \cdot 04$ & $2 \cdot 818(6)$ & 150 \\
& $\mathrm{~N}(31)-\mathrm{H}(31) \cdots \mathrm{O}(104)^{\mathrm{i}}$ & $2 \cdot 30$ & $3 \cdot 083(7)$ & 151 \\
& $\mathrm{~N}(32)-\mathrm{H}(32) \cdots \mathrm{O}(104)^{\mathrm{j}}$ & $2 \cdot 47$ & $3 \cdot 096(8)$ & 130 \\
$\mathbf{9}$ & $\mathrm{O}(1 \mathrm{~W})-\mathrm{H}(11 \mathrm{~W}) \cdots \mathrm{O}(16)^{\mathrm{k}}$ & $2 \cdot 06(6)$ & $2 \cdot 765(6)$ & $169(8)$ \\
& $\mathrm{O}(1 \mathrm{~W})-\mathrm{H}(12 \mathrm{~W}) \cdots \mathrm{O}(26)^{1}$ & $2 \cdot 10(6)$ & $2 \cdot 868(6)$ & $169(6)$ \\
& $\mathrm{N}(12 \mathrm{~B})-\mathrm{H}(12 \mathrm{C}) \cdots \mathrm{O}(31 \mathrm{~B})^{\mathrm{m}}$ & $2 \cdot 54$ & $3 \cdot 128(1)$ & 127 \\
& $\mathrm{~N}(12 \mathrm{~B})-\mathrm{H}(12 \mathrm{C}) \cdots \mathrm{O}(102)^{\mathrm{n}}$ & $2 \cdot 14$ & $2 \cdot 88(4)$ & 145 \\
& $\mathrm{~N}(22 \mathrm{~A})-\mathrm{H}(22 \mathrm{~A}) \cdots \mathrm{O}(200)^{\mathrm{o}}$ & $2 \cdot 26$ & $3 \cdot 110(2)$ & 171 \\
$\mathbf{1 0}$ & $\mathrm{N}(22 \mathrm{~B})-\mathrm{H}(22 \mathrm{C}) \cdots \mathrm{O}(32 \mathrm{~B})^{\mathrm{p}}$ & $2 \cdot 01$ & $2 \cdot 867(1)$ & 177 \\
$\mathbf{1 1}$ & $\mathrm{N}(22 \mathrm{~B})-\mathrm{H}(22 \mathrm{~B}) \cdots \mathrm{O}(101)^{\mathrm{q}}$ & $1 \cdot 957$ & $2 \cdot 796(5)$ & 165 \\
& $\mathrm{~N}(12 \mathrm{~A})-\mathrm{H}(12 \mathrm{~A}) \cdots \mathrm{O}(2 \mathrm{M})^{\mathrm{r}}$ & $2 \cdot 30$ & $3 \cdot 010(7)$ & 140 \\
& $\mathrm{~N}(12 \mathrm{~B})-\mathrm{H}(12 \mathrm{C}) \cdots \mathrm{S}(100)^{\mathrm{s}}$ & $2 \cdot 72$ & $3 \cdot 500(6)$ & 151
\end{tabular}

ISymmetry operators: (a) $1 / 2+x, 3 / 2-y, 1 / 2+z$; (b) $3 / 2-x, 1 / 2+y, 3 / 2-z$; (c) $3 / 2-x, 1 / 2+y, 3 / 2-z$; (d) $-x, 1+y, 1 / 2-z$; (e) $-1 / 2-x,-1 / 2+y, 1 / 2-z$; (f) $x, y$, $z$; (g) $x, 1+y, z$; (h) $-1 / 2+x,-1 / 2-y, z$; (i) $x,-1+y, 1+z$; (j) $x,-1+y, 1+z$; (k) $-1-x,-y, 1-z$; (1) $1+x, 1+y,-1+z$; (m) $1 / 2-x, y, 1 / 2+z$; (n) $1 / 2-x, y,-1 / 2+z$; (o) $x, 1 / 2+y, 3 / 2+z$; (p) $1 / 2-x, y,-1 / 2+z$; (q) $1-x, 1-y,-z$; (r) $1+x, y, z$; (s) $-1+x, y, z$.

(a)

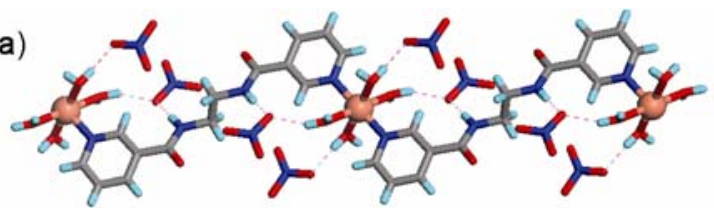

(b)
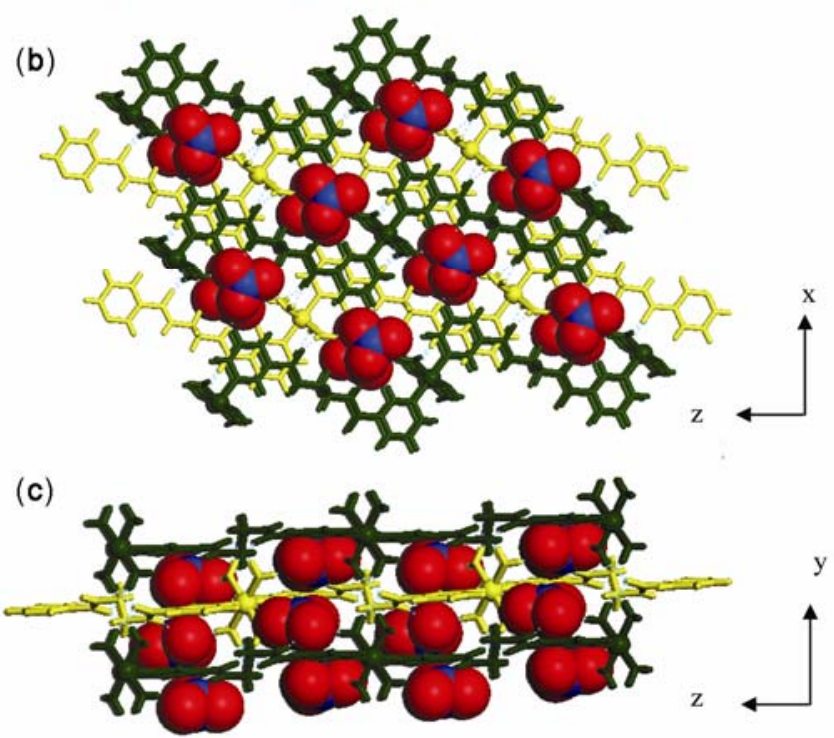

Figure 1. Illustrations for crystal structure of complex 4: (a) 1D chain, which shows the hydrogen bonds between the amide group and $\mathrm{NO}_{3}$ anion; packing of the chains resulted in channels occupied by $\mathrm{NO}_{3}$ anions; (b) top view and (c) side view; $\mathrm{NO}_{3}$ anions are shown in space fill mode and the middle layer was shown in light colour. as the plane of the phenyl ring is perpendicular to those of the two pyridyl rings (figure 3a). The 1Dchains are linked by the hydrogen bonded interactions between the amide groups and the $\mathrm{H}_{2} \mathrm{O}$ molecules to form a 2D-layer (figure 3c). This resulted in the formation of pattern which is similar to the $\beta$-sheet type. The $\mathrm{H}_{2} \mathrm{O}$ molecules are acting as mediator/connectors between the $-\mathrm{NH}$ and $\mathrm{C}=\mathrm{O}$ of the amide groups. These 2D-layers are further packed via aromatic interactions between the phenyl group and the pyridyl groups (figure $3 \mathrm{~d}$ ).

3.1d 1D Chain with rhomboidal cavities assembled via $\beta$-sheet hydrogen bonds: In complex 7, the $\mathrm{Cu}(\mathrm{II})$ centre adopts octahedral environment with four ligand units at equatorial sites and $\mathrm{ClO}_{4}$ anions at axial sites. The ethyl spacer of the ligand 2a exhibits gauche conformation, both the amide moieties of the ligand are anti to each other. This results in arc-like ligand geometry, which joins the $\mathrm{Cu}$ (II) centers and form $1 \mathrm{D}$ chain with rhomboidal cavities of dimensions $13.0 \AA \times 12.3 \AA$ (figure $4 \mathrm{a}$ ). The rhomboidal cavities are occupied by $\mathrm{CHCl}_{3}$ dimers, which are held together by $\mathrm{Cl}$... Cl interactions (3.641 $\AA, 3.920 \AA$ ) (figure 4b). These dimers fit in the cavities such that $\mathrm{C}-\mathrm{Cl}$ moieties lie within the cavities while $\mathrm{C}-\mathrm{H}$ groups point out of the 
(a)

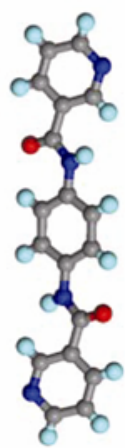

(b)

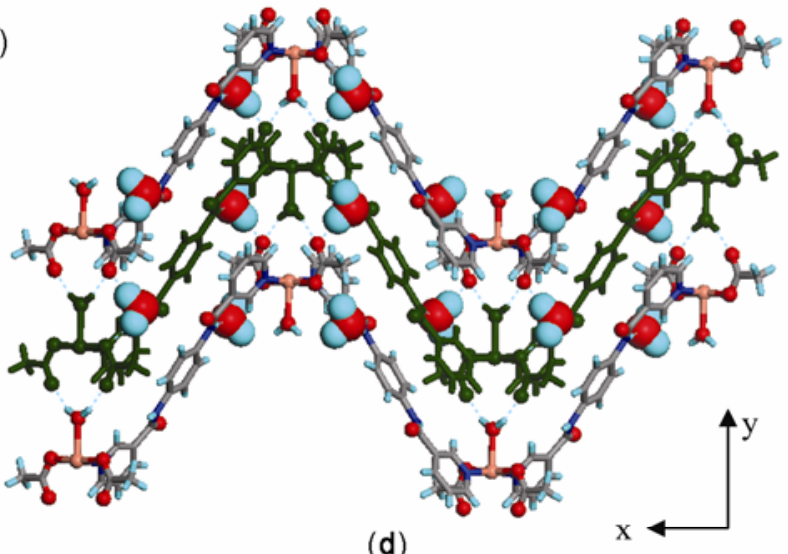

(d)

(c)

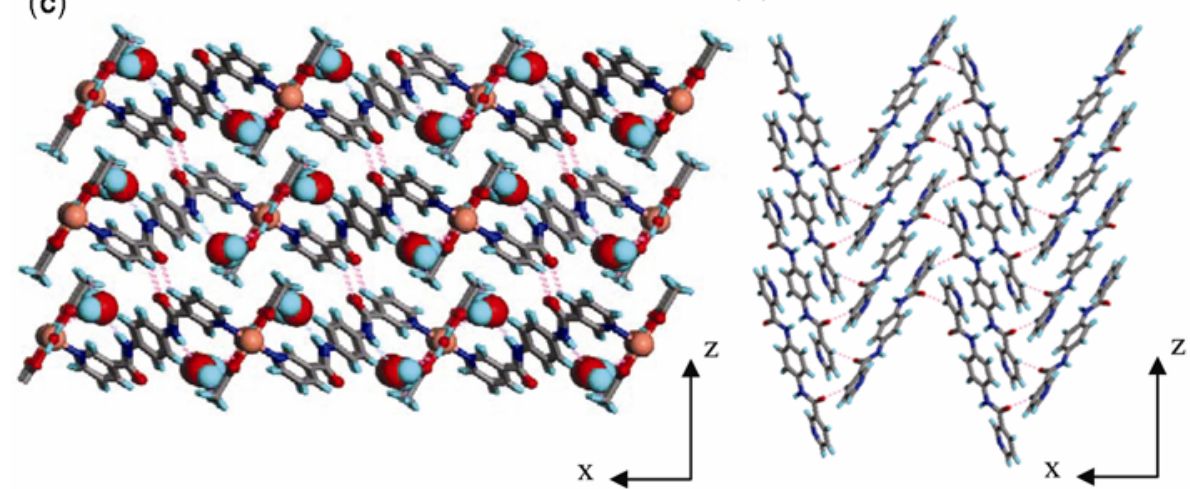

Figure 2. Illustrations for the crystal structure of 5: (a) geometry of ligand 1c in the complex; (b) packing of wave-like 1D chains to form 2D layer; (c) side view of the packing of the $2 \mathrm{D}$ layers via $\mathrm{C}-\mathrm{H} \cdots \mathrm{O}$ hydrogen bonds, free water molecule shown in space fill mode; (d) $\mathrm{C}-\mathrm{H} \cdots \mathrm{O}$ hydrogen bonds network between the ligands.

(a)

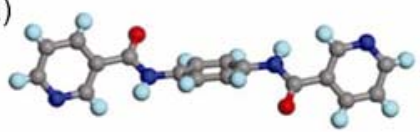

(c)

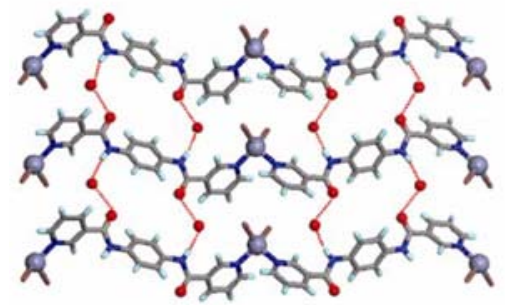

(b)

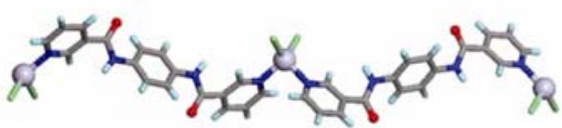

(d)

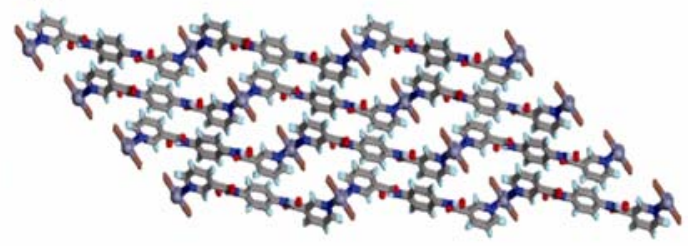

Figure 3. Illustrations for the crystal structure of 6: (a) geometry of the ligand 1c in the complex; (b) 1D chain; (c) packing of the 1D chains via $\beta$-sheet type hydrogen bonds to form a 2D-layer; (d) side view of the layers, which shows the packing of the layers via aromatic interactions.

cavities. The $\mathrm{C}-\mathrm{H}$ groups of these dimers are further bonded to coordinated $\mathrm{ClO}_{4}^{-}$via $\mathrm{C}-\mathrm{H} \cdots \mathrm{O}$ hydrogen bonds $\left(2 \cdot 600 \AA, 3 \cdot 445 \AA, 144 \cdot 43^{\circ}\right)$.
These chains form a layer via $\mathrm{C}-\mathrm{H} \cdots \mathrm{O}$ hydrogen bonds between pyridyl $\mathrm{C}-\mathrm{H}$ groups and $\mathrm{ClO}_{4}^{-}$ $\left(\mathrm{C}-\mathrm{H} \cdots \mathrm{O}: \quad 2.646 \AA, \quad 3.383 \AA, \quad 136 \cdot 60^{\circ}\right)$. The 2D- 


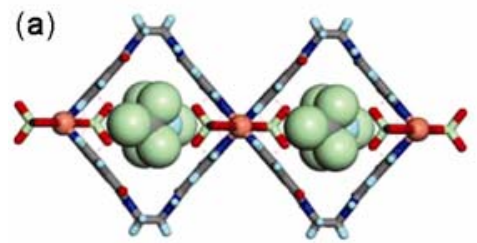

(b)

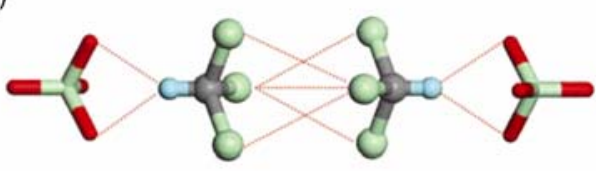

(c)

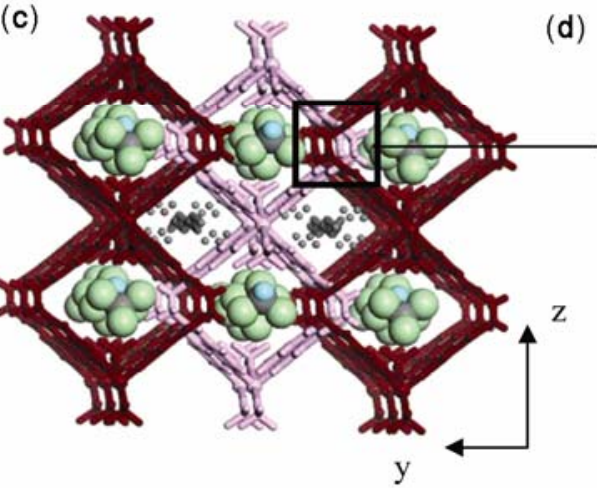

(d)

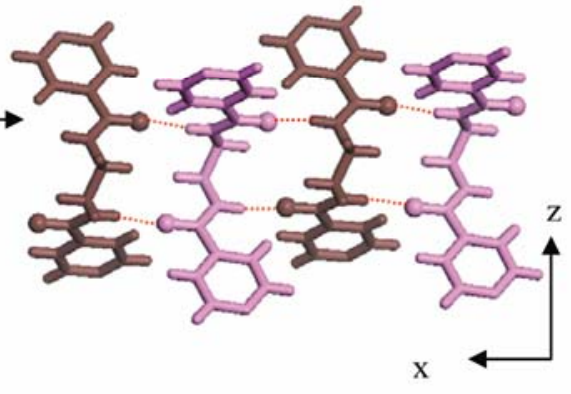

Figure 4. Illustrations for the crystal structure of 7: (a) 1D chain with rhomboidal cavities; (b) $\mathrm{CHCl}_{3}$ dimers, which are present in the cavities; (c) packing of the chains via $\beta$-sheet hydrogen bonds; (d) $\beta$-sheet.

layers pack via interdigitation, which occurs via $\beta$ sheet (figures $4 \mathrm{c}$ and d). Further this type of packing results in two types of channels, one of which is occupied by $\mathrm{CHCl}_{3}$ and the other is occupied by EtOH molecules. It is found that these cavities in 1D-chain are suitable only for $\mathrm{CHCl}_{3}$, as the reactions with other guest molecules failed to produce crystalline materials. Here it is important to note that the previously reported 1D structure of $\mathbf{2 a}$ with $\mathrm{Cu}\left(\mathrm{ClO}_{4}\right)_{2}$ neither contains guest molecules, nor contains $\beta$-sheet. ${ }^{15}$

3.1e ID Chains for inclusion of aromatic guests: The complex 8 also shows the formation of similar type of 1D chain as 7 but there exists some important structural differences. In complex 8, the axial positions are occupied by $\mathrm{H}_{2} \mathrm{O}$ molecules whereas in 7, $\mathrm{ClO}_{4}^{-}$anions were present at the axial position. The cavities formed in $\mathbf{8}$ have rectangular geometry with the dimensions of $10.0 \AA \times 13.8 \AA$ (figure 5a), whereas in 7 they are almost rhomboidal $(13.0 \AA \times 12.3 \AA)$. Further, the amide moieties in complex 8 are $s y n$ to each other (figure $5 \mathrm{~b}$ ). In complex 7, the amide moieties are anti to each other. Also one of the important differences between 7 and 8 is that in 7, the chains interact with each other via $\beta$-sheet hydrogen bonds whereas in $8 \beta$-sheet hydrogen bonds are absent. Regarding differences in the nature of the cavities of $\mathbf{7}$ and $\mathbf{8}$, it was observed that in 7 , the cavities are suitable only for $\mathrm{CHCl}_{3}$, as the reactions with other guest failed to produce crystalline materials. The cavities in $\mathbf{8}$ are good enough to accommodate several aromatic guest molecules such as naphthalene, toluene, xylene, anisole, nitrobenzene and ethylbenzene. Also the guest occupied volume of $8(22 \%)$ is much less than that of $7(22 \%$ $\left.\mathrm{CHCl}_{3}+19 \% \mathrm{EtOH}\right)$.

The structure of $\mathbf{8 a}$, which has naphthalene in the cavities, shows that the naphthalene molecules are sandwiched by four amide moieties of the ligands via $\pi-\pi$ interactions (figure $5 \mathrm{~d}$ ). Besides, amide groups are also involved in extensive hydrogen bonding (not amide-to-amide) with the water molecules and the $\mathrm{ClO}_{4}^{-}$(figure 5c). Accordingly, 1Dchains are joined together by $\mathrm{ClO}_{4}^{-}$by forming the hydrogen bonds with amide and coordinated $\mathrm{H}_{2} \mathrm{O}$. These layers pack with perfect overlap on each other such that the rhomboidal cavities are converted into channels (figure 5d). Along these channels, the edges of naphthalene molecules interact with each other via $\pi-\pi$ interactions (figure $5 \mathrm{e}$ ). These layers are glued together by $\mathrm{O}-\mathrm{H} \cdots \mathrm{O}$ hydrogen bonds between the $\mathrm{C}=\mathrm{O}$ of $\mathbf{1 a}$ and coordinated and uncoordinated $\mathrm{H}_{2} \mathrm{O}$ molecules.

The full structural analysis has been carried out for one more complex (8b) where the toluene acts as a guest. This structure confirms that disordered toluene occupies the cavities in 1D-chain similar to the 
(a)

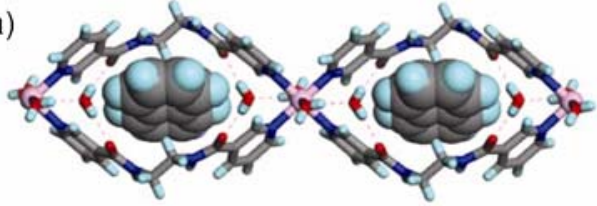

(b)

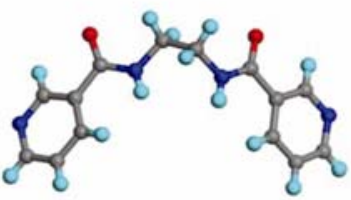

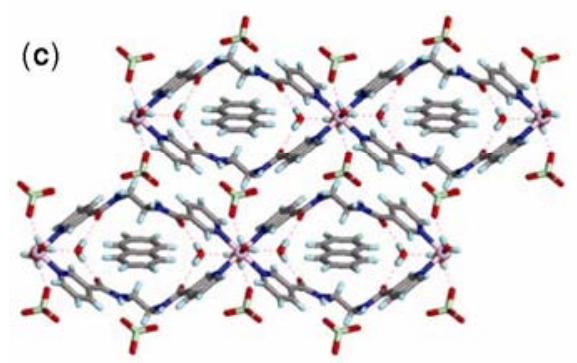

(d)

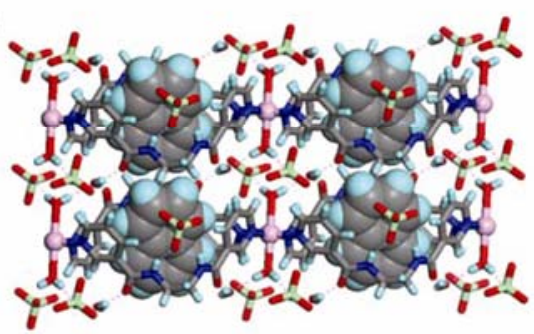

(e)

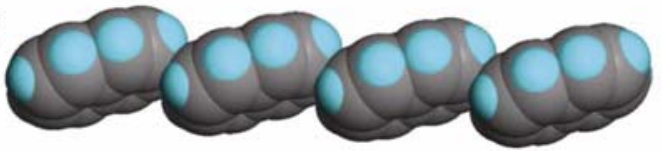

Figure 5. Illustrations for the crystal structure of 8a: (a) 1D chain with naphthalene molecules (space fill mode) included in rhomboidal cavities; (b) ligand geometry in the complex; packing of the chains via $\mathrm{N}-\mathrm{H} \cdots \mathrm{O}$ and $\mathrm{O}-\mathrm{H} \cdots \mathrm{O}$ hydrogen bonds (c) sideways linking of 1D chains; (d) top-bottom linking of 1D-chains; (e) column of naphthalene molecules, which are accommodated in channels.

(a)

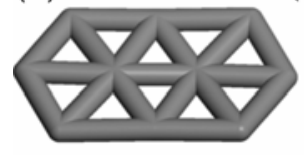

(b)

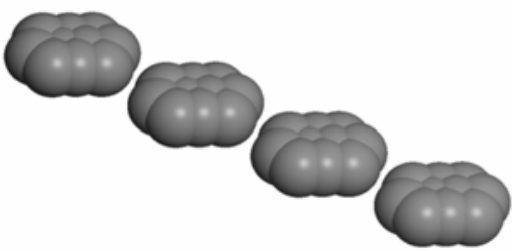

Figure 6. Toluene molecules in complex 8b: (a) disordered molecule; (b) column of toluene molecules which are accommodated in the channels of complex $\mathbf{8 b}$.

naphthalene in 8a (figures $6 \mathrm{a}$ and $\mathrm{b}$ ). The cell parameters were determined for the other complexes with guest molecules such as anisole, ethylbenzene, $p$-xylene, nitrobenzene, benzonitrile, biphenyl and found that they also have the similar unit cell parameters as $\mathbf{8 a}$ and $\mathbf{8 b}$. Here, it is interesting to note that using $1 \mathrm{a}$ and $\mathrm{Zn}\left(\mathrm{ClO}_{4}\right)_{2}$ similar $1 \mathrm{D}$ chain that contains smaller guest molecule such as $\mathrm{CH}_{3} \mathrm{CN}$ in cavities was reported earlier. ${ }^{16}$

\subsection{Crystal structures of complexes of reverse} amides

3.2a ID Chain containing rectangular cavities assembled via $\beta$-sheet hydrogen bonds: In complex 9, the $\mathrm{Cu}(\mathrm{II})$ centre adopts octahedral environ- ment and four ligand units occupy the equatorial sites. Unlike in $\mathbf{7}$ and $\mathbf{8}$, the axial sites are occupied by one $\mathrm{ClO}_{4}$ anion and one water molecule (figure 7a). The ethyl spacer of the ligand 3a exhibits gauche conformation (figure $7 \mathrm{~b}$ ) and the amide moieties in 3a are placed syn to each other. This type of geometry gives an arc-like shape to the ligand which joins the $\mathrm{Cu}(\mathrm{II})$ centers to form 1D chain with rectangular cavities of dimensions $14.0 \AA \times 11.4 \AA$, similar to the one observed in complex $\mathbf{8}$. However in $\mathbf{8}$, the cavities are occupied by various aromatic guest molecules while in 9 they are occupied by solvent $\left(\mathrm{H}_{2} \mathrm{O} / \mathrm{MeOH}\right)$ molecules. Another, important difference between 7, 8 and 9 is that the packing of the chains: in 7, both edges of the 1D chains interact with each other via $\beta$-sheet hydrogen bonds whereas in 9 one edge of the chain is involved in amide-to-amide hydrogen bond via $\beta$-sheet through interdigitation and the amide groups on the other edge are hydrogen bonded to water molecules (figure $7 \mathrm{c}$ ). While in $\mathbf{8}$, no such $\beta$-sheet hydrogen bonds were observed.

The packing of these one-dimensional chains along $\mathrm{X}$-axis results in three types of channels, two are of rectangular geometry and one is of triangular geometry. Bigger rectangular cavities are filled by solvent molecules and the other cavities are filled by 

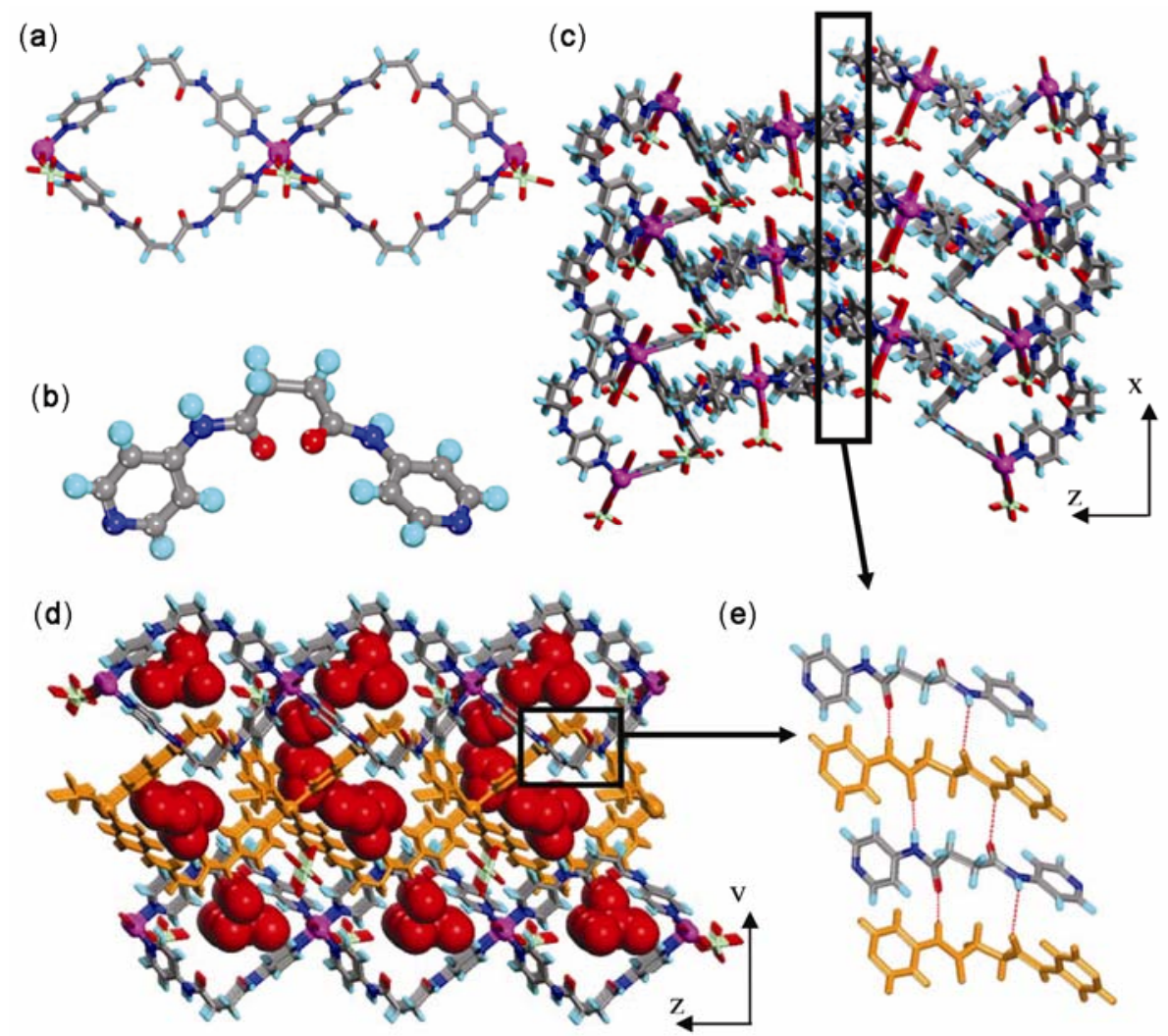

Figure 7. Illustrations for the crystal structure of 9: (a) 1D chain with rectangular cavities; (b) ligand geometry in the complex; 3D-packing of chains; (c) view along the metal atoms; (d) side view, notice that the packing of chains via $\beta$-sheets and also only one edge of the network is involved in the $\beta$-sheet formation; (e) $\beta$-sheet hydrogen bonds.

perchlorate anions (figure 7d). Apart from $\beta$-sheet pattern these networks further connected through hydrogen bonds between coordinated perchlorate, water and amide groups. Our efforts to include guest molecules were not successful in obtaining crystalline materials.

3.2b Zig-zag $1 D$ chain: In complex 10, the $\mathrm{Cu}(\mathrm{II})$ centre adopts octahedral coordination geometry and the ligand $\mathbf{3 b}$ exhibits two types of geometries. One (A) contains all anti conformation for butyl spacer whereas the other (B) contains disordered butyl group with anti-gauche-anti conformation (figures $8 \mathrm{a}$ and $\mathrm{b}$ ) and the asymmetric unit contains only half units of A and B as they sit on crystallographic symmetry. The two ligand (3b) units occupy the two equatorial sites in a syn fashion; one sulphate anion and one water molecule occupy the remaining two equatorial sites. The axial positions are coordinated by water molecules. Due to the syn coordination of the ligand to the metal centre resulted in the formation of zig-zag 1D chain (figure $8 \mathrm{c}$ ). The geometry of the ligand $\mathrm{B}$ gives a curvature to $1 \mathrm{D}$-chain which helps in the interlocking with two of the adjacent chains. The interlocking of the chains in ac-plane generates a twodimensional layer which is highly corrugated. Generally, several examples of interlocking exist for macro-cycles, 2D-layers and 3D-networks. To our knowledge, this is the first example of 1D-chains with such interlocking. The primary interactions responsible for such interlocking are found to be $\mathrm{O}-\mathrm{H}$... O hydrogen bonds between coordinated water and amide carbonyl of A (O‥O distance: $2.791 \AA)$ (figure 8d). The pyridine groups also involved in edge to edge aromatic interactions with each other (C...C distances: $3.699 \AA, \quad 3.742 \AA, \quad 4.035 \AA$, $4 \cdot 179 \AA$ ). The $\mathrm{N}-\mathrm{H}$ group of $\mathrm{A}$ hydrogen bonds to water molecules $\left(1.949 \AA, 167.67^{\circ}, 2.796 \AA\right)$ while the $\mathrm{N}-\mathrm{H}$ groups in $\mathrm{B}$ hydrogen bonds to sulphate O-atom $\left(1.958 \AA, 164.56^{\circ}, 2.796 \AA\right)$. The carbonyl groups of B hydrogen bonds to free water molecules 
(a)

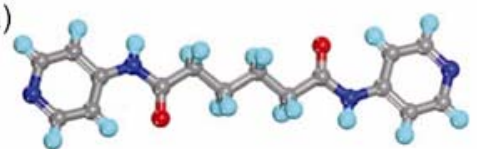

(b)

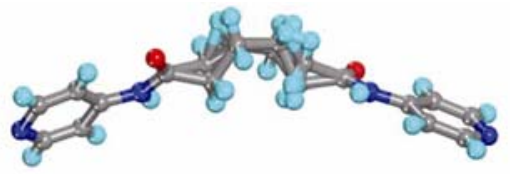

(d)

(c)

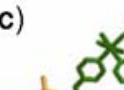

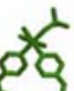

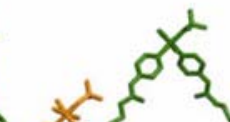

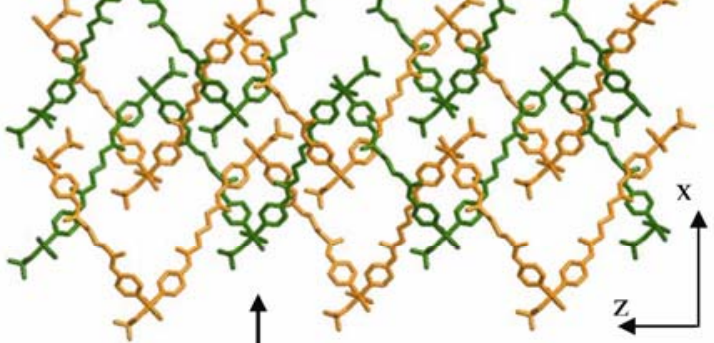

(e)

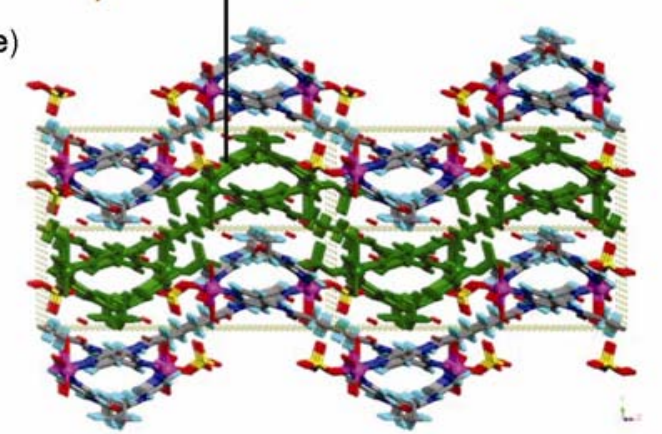

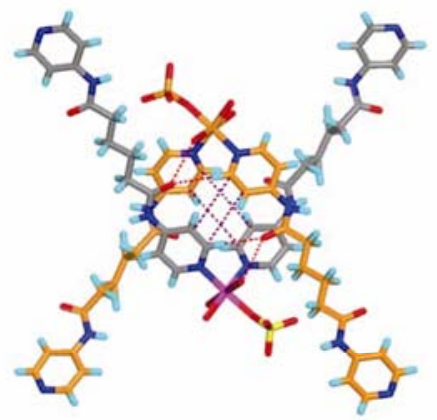

Figure 8. Illustrations for the crystal structure of 10: Geometry of the ligand (a) A exhibits all anti $\mathrm{CH}_{2}$ groups; (b) B with anti-gauche-anti $\mathrm{CH}_{2}$ groups (disordered); (c) interlocking of adjacent chains; (d) interactions at the interlocking point and (e) the 3D packing of the chains.

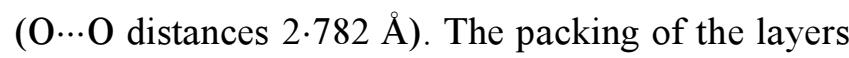
is governed by plethora of strong and weak hydrogen bonds (figure 8e).

3.2c Linear 1D chain: In complex $\mathbf{1 1}$, two independent 1D chains $\mathrm{X}$ and $\mathrm{Y}$ are present and the $\mathrm{Cu}$ (II) centre adopts octahedral coordination geometry in both the chains. The ligand $\mathbf{3 c}$ in chain $\mathrm{X}$ is coplanar with the interplanar angle between the amide and pyridyl plane is $7.74^{\circ}$, while in chain $\mathrm{Y}$ the 3c deviates more from planarity with the interplanar angle of $17.76^{\circ}$ (figures $9 a$ and $b$ ). In both the chains the equatorial position of $\mathrm{Cu}$ (II) are occupied by two ligand units and two thiocyanate anions while the axial positions are occupied by DMSO which are disordered in chain-Y.

These chains are interconnected in ac plane via $\mathrm{N}-\mathrm{H} \cdots \mathrm{O} \quad\left(2.289 \AA, \quad 140.55^{\circ}, 3.003 \AA\right)$ hydrogen bonds between the amide $\mathrm{N}-\mathrm{H}$ of chain $\mathrm{Y}$ and $\mathrm{O}$-atom of DMSO of chain $\mathrm{X}$ (figure 9c). The $\mathrm{N}-\mathrm{H}$ groups of chain $\mathrm{X}$ are connected to the $\mathrm{S}$-atom of
SCN of the chain Y via N-H...S $\left(2.732 \AA, 150.53^{\circ}\right.$, $3.507 \AA ; 2.923 \AA, 135.97^{\circ}, 3.649 \AA$ ) interactions, several other weak interactions such as edge to face $\mathrm{C}-\mathrm{H} \cdots \pi$ interaction between the pyridine and central phenyl ring of 3c (C...C distances 3.6-4.0 $\AA$ ) exist between the adjacent chains $X$ and $Y$ (figure 9d).

\subsection{Thermal gravimetric analyses}

Thermo gravimetric analyses have been performed on the complex $\mathbf{8}$ as it has shown an ability to include several aromatic guest molecules in its cavities. The analyses show that the weight loss observed in complexes of $\mathbf{8}$ follow the same pattern and does not depend on the type of guest molecules present in the network. When naphthalene is present as guest molecule (8a), the $12.6 \%$ of weight loss observed till $168^{\circ} \mathrm{C}$ corresponds to the loss of naphthalene molecules from the network (calculated: $12.7 \%$ ). The weight loss of $2.5 \%$ observed in the temperature range 168 to $210^{\circ} \mathrm{C}$ corresponds to the 
(a)

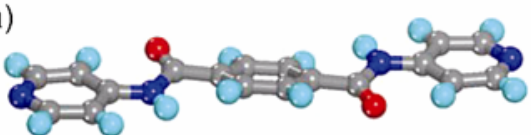

(b)

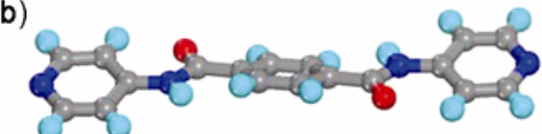

(c)

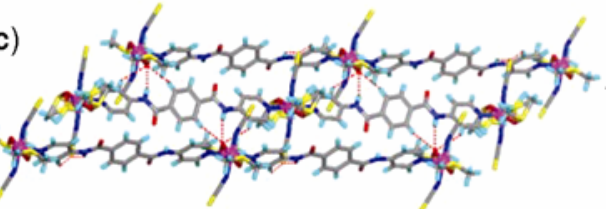

(d)

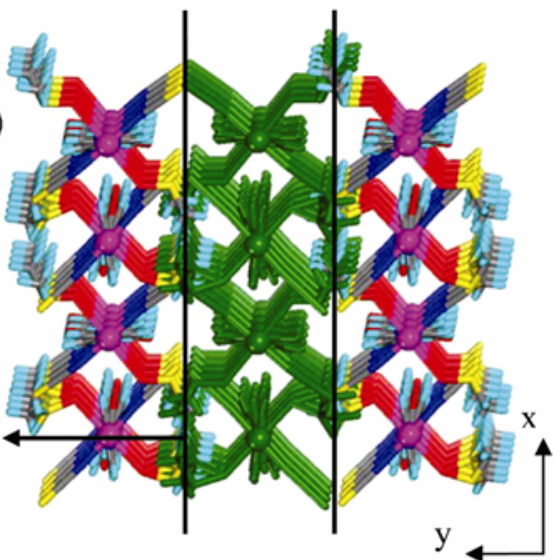

Figure 9. Illustrations for the crystal structure of 11: Geometry of ligand 3c in (a) chain-X; (b) chain-Y; (c) interactions between chain-X and chain-Y and (d) 3D packing of chains.

(a)

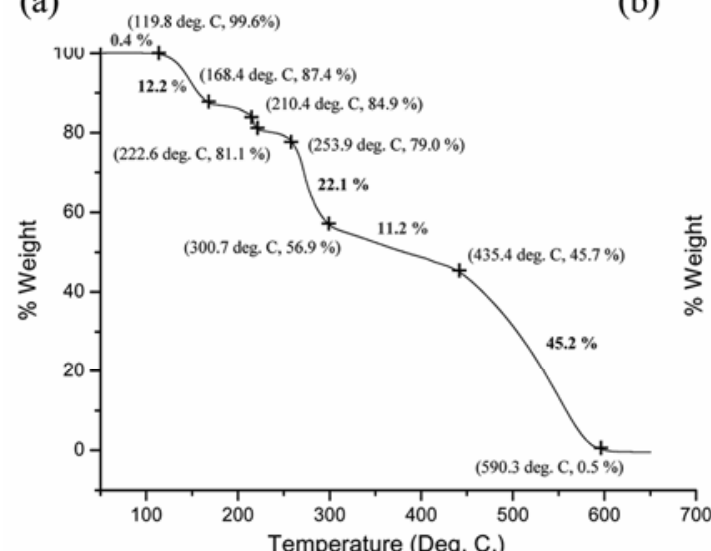

(b)

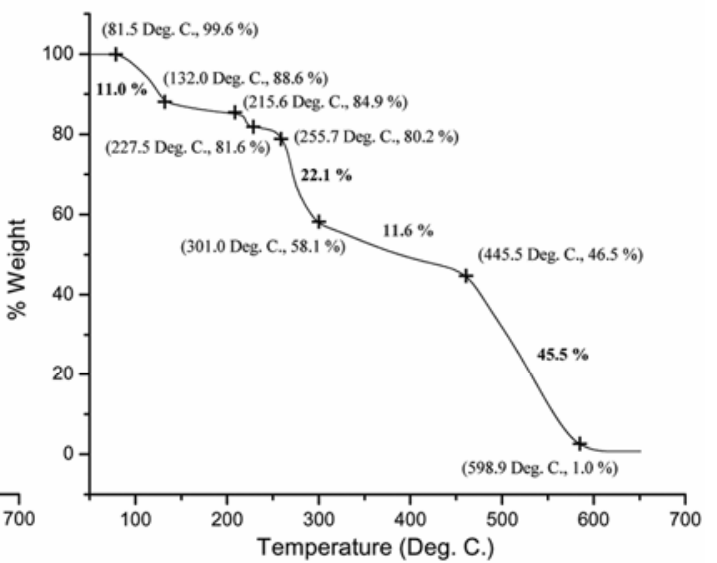

(d)

(c)

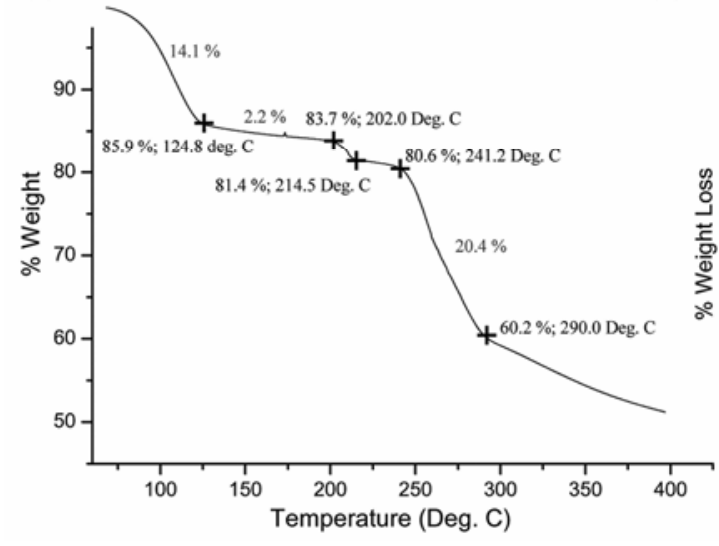

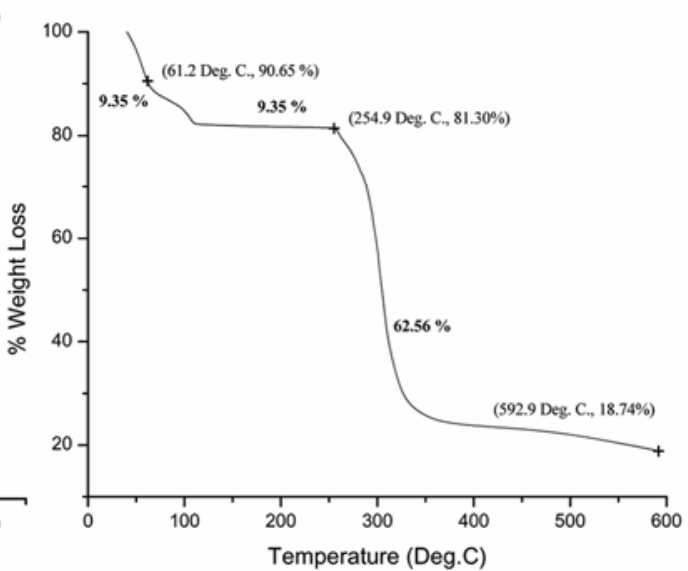

Figure 10. TGA of complexes (a) 8a; (b) 8b; (c) 8c; (d) 11.

loss of one water molecule (calculated: $2 \cdot 1 \%$ ). Further weight loss of $3.8 \%$ from 210 to $222^{\circ} \mathrm{C}$ corresponds to the loss to two molecules of water (calculated: $4 \cdot 2 \%$ ) and $2 \cdot 1 \%$ of weight loss in the temperature range of 222 to $253^{\circ} \mathrm{C}$ corresponds to the loss of remaining one water molecule from the network (calculated: $2 \cdot 1 \%$ ). The network found to collapse after $253^{\circ} \mathrm{C}$ due to the loss of the ligand molecules (figure 10a).

Similar trend of weight loss was observed with

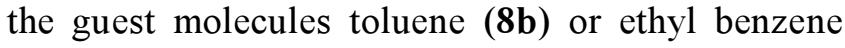
(8c). The initial weight loss corresponds to the loss 
of aromatic guest molecules followed by the loss of the water molecules. In complex $8 \mathbf{b}, 11.4 \%$ of weight loss at $132^{\circ} \mathrm{C}$ corresponds to the loss of toluene (calculated: $12 \cdot 4 \%$ ). $8 \cdot 4 \%$ weight loss from $132^{\circ} \mathrm{C}$ to $255^{\circ} \mathrm{C}$ corresponds to the loss of three $\mathrm{H}_{2} \mathrm{O}$ (calculated: $8.3 \%$ ). The network is stable up to $255^{\circ} \mathrm{C}$ (figure 10b). In complex 8c, $14.1 \%$ of weight loss at $124^{\circ} \mathrm{C}$ corresponds to the loss of ethylbenzene (calculated: 13.4\%). 6.1\% weight loss from $124^{\circ} \mathrm{C}$ to $241^{\circ} \mathrm{C}$ corresponds to the loss of three $\mathrm{H}_{2} \mathrm{O}$ (calculated: $7.8 \%$ ). The network is stable up to $241^{\circ} \mathrm{C}$ (figure $10 \mathrm{c}$ ).

In complex $10,9.35 \%$ of the weight loss observed till $61^{\circ} \mathrm{C}$ corresponds to the loss of three free water molecules from the network (calculated: 9.54\%). The weight loss of $9.35 \%$ observed in the temperature range of 61 to $255^{\circ} \mathrm{C}$ corresponds to the loss of three coordinated water molecules (calculated: $9.54 \%$ ). The complex is stable till $255^{\circ} \mathrm{C}$ and after that it collapses due to the loss of the ligand molecules (figure 10d).

\section{Conclusions}

The 1D networks with the ligands 1-3 mainly exhibited three types of geometries: (i) linear chains (4 and 11), (ii) wavy chains (5, 6 and 10) and (iii) chains with cavities (7-9). The flexibility of the ligand resulted in the formation of arc type ligand geometry, which resulted in the formation of chains with cavities (type iii). Further, the cavities were shown to be included by guest molecules or solvents. The cavities of complex 7 and 9 have exhibited specificity for guest inclusion whereas those in complex 8 exhibited versatility to accommodate wide range of aromatic guest molecules.

The amide groups of the ligands in the complexes assembled the networks into higher dimensionalities. In complexes 4, 5 and 10 , the anions and $\mathrm{H}_{2} \mathrm{O}$ molecules formed hydrogen bonds with the amide groups. In case of complex $\mathbf{6}$, the amide groups were involved in hydrogen bonded interactions with itself ( $\beta$-sheet) and also with water molecules. In complex 7 , the chains were assembled via $\beta$-sheet hydrogen bonds while in complex 8 and 11, the amide groups are hydrogen bonded to anions/solvents. However, in complex 9, the amide groups exhibit amide-toamide ( $\beta$-sheet) as well as amide-to-solvents/anions hydrogen bonds. We note here that the complex $\mathbf{1 0}$ contains an unprecedented interlocking for onedimensional networks.

\section{Acknowledgements}

We gratefully acknowledge the financial support from Council of Scientific and Industrial Research (CSIR), Department of Science and Technology (DST)-Fund for Improvement of Science and Technology (FIST) for single crystal X-ray facility. LR thanks Indian Institute of Technology (IIT) (Kharagpur) for research fellowship.

\section{References}

1. (a) Desiraju G R 1989 Crystal engineering. The design of organic solids (Amsterdam: Elsevier); (b) Subramanian S and Zaworotko M J 1994 Coord. Chem. Rev. 137 357; (c) Crystal engineering: From molecules and crystals to materials (eds) D Braga and A G Orpen 1999 (NATO, Kluwer: Dordrecht, Netherlands: ASI Series); (d) Zaworotko M J 2001 Chem. Commun. 1; (e) Lehn J-M 1995 Supramolecular chemistry: Concepts and perspectives (Weinheim: VCH); (f) Atwood J L, Davies J E D, MacNicol D D and Vögtle F 1996 Comprehensive supramolecular chemistry (Oxford: Pergamon); (g) Macgillivray L R, Papaefstathiou G S, Friščić T, Hamilton T D, Bučar D K, Chu Q, Varshney D B and Georgiev I G 2008 Acc. Chem. Res. 41280

2. (a) Hagrman P J, Hagrman D and Zubieta J 1999 Angew. Chem. Int. Ed. 38 2639; (b) Li H, Eddaoudi M, O'Keeffe M and Yaghi O M 1999 Nature 402 276; (c) Moulton B and Zaworotko M J 2001 Chem. Rev. 101 1629; (d) Rosi N L, Eddaoudi M, Kim J, O'Keeffe, M and Yaghi O M 2002 Cryst. Eng. Comm. 4 401; (e) Lin W and Evans O R 2002 Acc. Chem. Res. 35 511; (f) Biradha K and Fujita M 2002 Angew. Chem. Int. Ed. 41 3392; (g) Kitagawa S, Kitaura K and Noro S-I 2004 Angew. Chem. Int. Ed. 43 2334; (h) Gianneschi N C, Masar III M S and Mirkin C A 2005 Acc. Chem. Res. 38 825; (i) Kitagawa S and Uemura K 2005 Chem. Soc. Rev. 2109

3. (a) Janiak C 2003 Dalton Trans. 2781; (b) James S L 2003 Chem. Soc. Rev. 32 276; (c) Biradha K 2003 Cryst. Eng. Comm. 5 374; (d) Rosseinsky M J 2004 Microporous Mesoporous Mater. 73 15; (e) Goldberg I 2005 Chem. Commun. 1243; (f) Kepert C J 2006 Chem. Commun. 695; (g) Kitagawa S, Noro S-I and Nakamura T 2006 Chem. Commun. 701; (h) Barbour L J 2006 Chem. Commun. 1163; (n) Thallapally P K, Tian J, Kishan M R, Fernandez C A, Dalgarno S J, McGrail P B, Warren J E and Atwood J L $2008 \mathrm{~J}$. Am. Chem. Soc. 130 16842; (o) Wang B, Côte A P, Furukawa H, O'Keeffe M and Yaghi O M $2008 \mathrm{Na}$ ture 453 207; (p) Ma L and Lin W 2009 Angew. Chem. Int. Ed. 48 3637; (p) Wang Z and Cohen S M 2009 Chem. Soc. Rev. 38 1315; (q) Li J-R, Kuppler R J and Zhou H-C 2009 Chem. Soc. Rev. 381477

4. (a) Desiraju G R 1995 Angew. Chem. Int. Ed. 34 2311; (b) Simard M, Su D and Wuest J D $1991 \mathrm{~J}$. Am. 
Chem. Soc. 113 4696; (c) Kepert C J, Prior T J and Rosseinsky M J $2000 \mathrm{~J}$. Am. Chem. Soc. 122 5158; (d) Desiraju G R 2002 Acc. Chem. Res. 35 565; (e) Ferlay S, Félix O, Hosseini M W, Planeix J-M and Kyritsakas N 2002 Chem. Commun. 702; (f) Beatty A M, Schneider C M, Simpsona A E and Zaher J L 2002 Cryst. Eng. Comm. 51 282; (g) Wuest J D 2005 Chem. Commun. 5830

5. (a) Sarkar M and Biradha K 2006 Cryst. Growth and Des. 6 202; (b) Rajput L; Singha S and Biradha K 2007 Cryst. Growth Des. 72788

6. (a) Sarkar M and Biradha K 2005 Chem. Commun. 2229; (b) Sarkar M and Biradha K 2006 Crystal Growth and Design 6 1742; (c) Sarkar M and Biradha K 2006 Eur. J. Inorg. Chem. 531; (d) Sarkar M and Biradha K 2007 Crystal Growth and Design 7 1318; (e) Rajput L and Biradha K 2008 Polyhedron 27 1248; (e) Rajput L and Biradha K 2009 Cryst. Growth Des. 9 3848; (h) Rajput L and Biradha K 2009 Cryst Eng Comm. 111220

7. (a) Khlobystov A N, Blake A J, Champness N R, Lemenovskii D A, Majouga A G, Zyk N V and Schröder M 2001 Coord. Chem. Rev. 222 155; (b) Barnett S A and Champness N R 2003 Coord. Chem. Rev. 246145

8. (a) Carlucci L, Ciani G, Proserpio D M and Sironi A 1997 J. Chem. Soc., Dalton Trans. 1801; (b) Tong ML, Cai J-W, Yu X-L, Chen X-M, Ng S W and Mak T C W 1998 Aust. J. Chem. 51 637; (c) Liu C M, You X Z and Chen W 1998 J. Coord. Chem. 46 183; (d) Dong Y-B, Smith M D, Layland R C and zur Loye H-C 2000 J. Chem. Soc., Dalton Trans. 775

9. (a) Park H W, Sung S M, Min K S, Bang H and Suh M P 2001 Eur. J. Inorg. Chem. 2857; (b) Chawla S K, Hundal M S, Kaur J and Obrai S 2001 Polyhedron 20 2105; (c) Li L, Chen B, Song Y, Li G, Hou H, Fan $\mathrm{Y}$ and Mi L, 2003 Inorg. Chim. Acta 34495

10. Biradha K, Seward C and Zaworotko M J 1999 Angew. Chem. Int. Ed. 38492
11. (a) Cussen E J, Claridge J B, Rosseinsky M J and Kepert C J 2002 J. Am. Chem. Soc. 124 9574; (b) Fletcher A J, Cussen E J, Bradshaw D, Rosseinsky M $\mathrm{J}$ and Thomas K M $2004 \mathrm{~J}$. Am. Chem.Soc. 126 9750; (c) Wagner B D, McManus G J, Moulton B and Zaworotko M J 2002 Chem. Commun. 2176; (d) Losier P and Zaworotko M J 1996 Angew. Chem. Int. Ed. Engl. 352779

12. (a) Aoyagi M, Biradha K and Fujita M 2000 Bull. Chem. Soc. Jpn. 73 1369; (b) Lu J Y, Runnels $\mathrm{K}$ A and Norman C 2001 Inorg. Chem. 40 4516; (c) Lu J Y and Norman C 2003 Polyhedron 22 235; (d) Woodward J D, Backov R, Abboud K A, Ohnuki H, Meisel M W and Talham D R 2003 Polyhedron 22 2821; (e) Izarova N V, Sokolov M N, Rothenberger A, Ponikiewski L, Fenske D and Fedin V P 2005 C. R. Chim. 8 1005; (f) Felloni M, Blake A J, Champness N R, Hubberstey P, Wilson C and Schröder M 2002 J. Supramol. Chem. 2 163

13. Yaghi O M, Li H and Groy T L 1997 Inorg. Chem. 364292

14. (a) Fujita M, Aoyagi M and Ogura K 1998 Bull. Chem. Soc., Jpn. 71 1799; (b) Kasai K, Aoyagi M and Fujita M $2000 \mathrm{~J}$. Am. Chem. Soc. 122 2140; (c) Suresh E and Bhadbhade M M 2001 Cryst. Eng. Comm. 13 1; (d) Zhao Q, Li H, Wang $X$ and Chen $Z$ 2002 New J. Chem. 26 1709; (e) Marsh R E 2004 Acta Crystallogr., Struct. Sci. B60 252

15. Ge C-H, Zhang X-D, Zhang P, Guan W, Guo F and Liu Q-T 2003 Polyhedron 223493

16. Muthu S, Yip J H K and Vittal J J 2002 J. Chem. Soc., Dalton Trans. 4561

17. Sheldrick G M, SHELX-97, Program for the solution and refinement of crystal structures; University of Göttingen, Göttingen, Germany, 1997

18. Spek A L PLATON-A multi purpose crystallographic tool, Utrecht University, Utrecht, The Netherlands, 2002 